\title{
GRAMMATICAL COHESION ON BROADCAST PROGRAM MBJ BY PMKJS IN RRI MADIUN
}

\author{
Nana Udawati ${ }^{1,}$ Sumarlam $^{2,}$ Sri Marmanto ${ }^{3}$ \\ ${ }^{1}$ Universitas Sebelas Maret Surakarta \\ nanaudawati@yahoo.com \\ ${ }^{2}$ Universitas Sebelas Maret Surakarta \\ sumarlamwd@gmail.com \\ ${ }^{3}$ Universitas Sebelas Maret Surakarta \\ srimarmanto01@gmail.com
}

\begin{abstract}
Abstrak
Penelitian ini bertujuan untuk menemukan kohesi gramatikal dalam siaran MBJ oleh Paguyuban Marsudi Kasusastran Jawi Sedyatama Jawi di RRI Madiun. Metode kualitatif deskriptif dalam penelitian ini mengarahkan pada tiga langkah dalam pemerolehan data, yakni pengumpulan data, analisis data, dan pemaparan data. Data diklasifikasikan ke dalam jenis-jenis aspek gramatikal. Data diperoleh dari siaran radio MBJ oleh PMKJS di RRI Madiun pada tanggal 8 Oktober 2014 dan 10 Desember 2014.Sumber data dalam penelitian ini merupakan transkripsi dari dua data yaitu siaran MBJ pada tanggal 8 Oktober 2014 dan 10 Desember 2014. Rekaman dan observasi ditambah dengan catatan digunakan dalam proses pengumpulan data. Dari hasil analisis penelitian ini memperlihatkan bahwa ditemukan aspek gramatikal yang berupa yaitu referensi, subtitusi, elepsis, dan konjungsi. Secara keseluruhan kohesi gramatikal dalam siaran MBJ berjumlah 1004 data.
\end{abstract}

Kata kunci: aspek gramatikal, kohesi, transkrip.

\section{INTRODUCTION}

Radio broadcast is one of the electronic means of communication used by the public to obtain information, send information, and obtain entertainment that is audial (Onong, 1990: 18). As a means of public communication, radio has a heterogeneous listener in terms of age, gender, profession, social status, economy, and so on. With such heterogeneous listeners, radio managers must be able to compose or create events that meet the demands of their audience. Therefore, radio managers compete to make an interesting event, so as to capture a lot of listeners. Events that attracted many listeners for example $M B J$ show on RRI Madiun. The event fascinated listeners especially people who were very interested in the case of Javanese culture. 
Oral discourse which is a discourse delivered with oral media. This is in accordance with Mulyana's opinion, (2005: 53) states that "Speaking discourse is a type of discourse delivered orally or directly with verbal language. The existence of the fact that basically the first language was believe to be acquired through oral. Oral discourse can be used as a means of communication to express and convey everything that is the fruit of thoughts, and feelings in the form of ideas or opinions. Oral discourse can be delivered directly face to face or delivered through the media, such as radio, television, or telephone. Discourse delivered by oral media can be used in various types of activities, one of which can be used in a radio broadcast event. Therefore, radio broadcasts can be categorized as oral discourse. The process of oral discourse in the conversation of radio broadcasting is also inseparable from the relationship between the discourse of the form of relationships called cohesion and the relationship of meaning called coherent (Sumarlam, 2013: 23). Cohesion basically refers to form relationships. This means that the elements of discourse (words or sentences) used to construct a discourse have a cohesive and intact relevance. Coherence is essentially a set of logical, organized facts and ideas. Coherence can occur implicitly (veiled) as it relates to areas of meaning that require interpretation (Mulyana, 2005: 26-31).

Based on the language used, discourse expressed by using the means of Javanese language called the discourse of the Javanese language (Sumarlam, 2003: 16). The Javanese language discourse may consist of Javanese varieties of ngoko (Javanese variety of subtle, low variety), krama (varieties of Javanese smooth, high variety), and the mixture of the two varieties is the variety of ngoko and krama. The discourse of the oral Javanese verbs of the variety of ngoko (eg snakes or sabdatama messages or good advice conveyed to the bride in the wedding ceremony), the discourse of the oral Javanese verbal krama (eg discourse pawartos basa Jawi 'news Javanese' on radio or television), and Javanese verbal discourses of various forms of mixed (eg, discourse of drama performances of wayang kulit or wayang orang, etc.). As a form of Javanese language application in the communication medium is the use of Javanese language in broadcasting news via radio electronic media. Among the electronic mass media that broadcast radio broadcast with the discourse of the Javanese language is RRI Madiun. Paguyuban Marsudi Kasusastran Jawi Sedyatama is one of the Javanese Language Society using the introduction language of Javanese addressing the secretariat on Jalan Usadasari no.17 Madiun. Paguyuban Marsudi Kasusastran Jawi Sedyatama only performs MBJ every month 2 times in RRI Madiun on Wednesday night at 
20.00 until 21.00 WIB. The broadcasting program is directly broadcast by RRI Madiun. Broadcast information that is packed about the case of Javanese culture.

In this study the author took the title of Grammatical Cohesion in MBJ Event by PMKJS in RRI Madiun. The reason is first, Gramatical Study on the MBJ program broadcast by PMKJS in RRI Madiun has never been done. Second, MBJ broadcast by Paguyuban Marsudi Kasusastran Jawi Sedyatama in RRI Madiun broadcast in East Javanese and surrounding areas by using the introduction in the form of Javanese krama alus. Third, in this research there is a discourse in the form of grammatical aspects. Fourth, MBJ program broadcast by Paguyuban Marsudi Kasusastran Jawi Sedyatama is an event program at RRI Madiun in which there is an interesting dialogue about sub-case and culture of Javanese. MBJ broadcast is also a form of effort in the preservation of Javanese language, so it needs to be developed through research so that the script discourses and delivery to be better.

This research describes the rhetorical structure of the preliminary part of Indonesian language research journal articles in the field of literature and describes the linguistic features of the introduction of Indonesian journal journal articles in the field of literature; this research uses descriptive research method. Data and data sources in this study is a document in the form of speech writers in the text discourse while the data source in the form of research journal articles in the field of literature. The analysis of rhetorical structure uses MMP theory consisting of 4 stages and 18 steps, while linguistic features are defined as the use of the type or variety of texts associated with active and passive sentences, types of clauses, conjunctions / connections. Novia Juita (2016) studies Tindak Tutur Tokoh dalam Kaba on a number of kaba Minangkabau selected as data sources. Kaba is chosen as the source of data since there is assumptions that the characters in the tale is polite in speaking, attitude (knows the tendency) 'wise'. Speech acts have certain characteristics that are spoken by using a certain strategy, and interpreted as a wise and polite speech act. The results of this study can be utilized to encrich the lecture material, such as, in the course Philosophy of Minangkabau culture, Folklore, Introduction to Social and Culture Sciences.

\section{RESEARCH METHOD}

This study is a qualitative-descriptive research and using discourse analysis approach. The location of this research is demographic; the place of this research is at RRI Jalan Mayjend Panjaitan number 10 Madiun. Participants are all participants involved in 
conversation of oral discourse in the event of MBJ siaram by PMKJS. The incident studied was the conversation of oral discourse during the broadcast lasted until completion. Data source in this research is broadcast of MBJ by PMKJS on October 8, 2014 and December 10, 2014. The data of this research is the oral discourse of broadcast of Cultural Memetri Jawi by PMKJS on October 8, 2014 and December 10, 2014 which (already recorded previously) and the result of review From previous research. This study uses document analysis techniques.

\section{FINDINGS AND DISCUSSION}

\section{A. Grammatical Aspects}

Grammatical aspects are aspects of the form or structure which establish a discourse. Grammatical cohesion in discourse can be divided into four kinds of reference, substitution, ellipsis, and conjunction.

\section{B. Reference}

Reference is one type of grammatical cohesion in the form of a particular lingual unit that refers to another lingual unit (or a reference) that precedes or follows it. According to the place, whether the reference is in the text or outside the text, the reference is divided into two types; (1) endoopathic reference when the reference (lingual unit referred to) resides or is present within the text of the discourse, and (2) ekpofora reference when the reference is or is located outside the text of the discourse. The first type of cohesion, endofora reference based on the direction of pengacuannya divided into two types again, namely anaphoric reference and cataphoric reference.

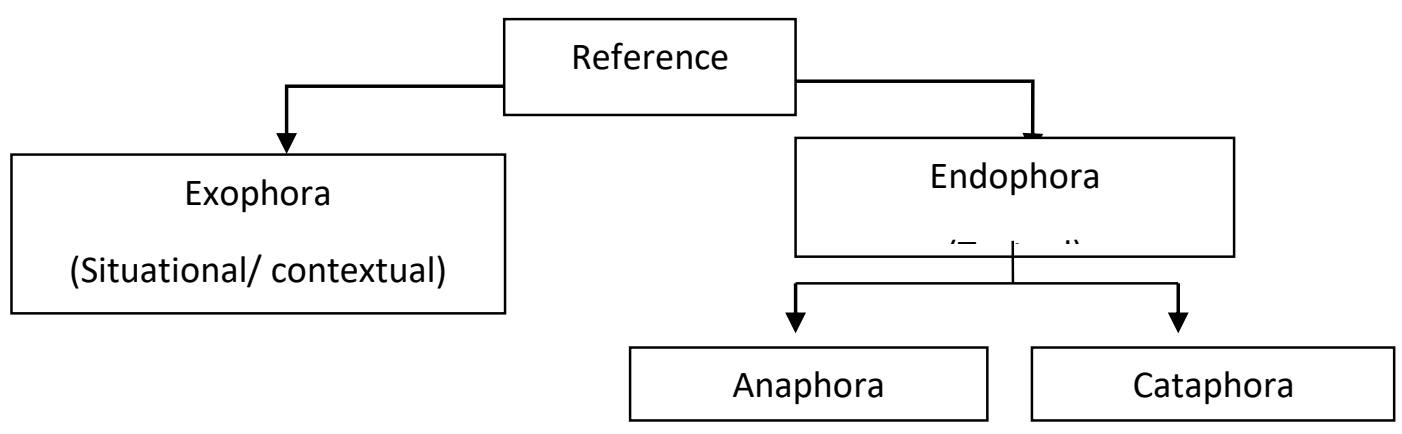

\section{Chart 1: Types of references}

Anaphoric reference is one of the grammatical cohesions in the form of a particular lingual unit which refers to another lingual unit which proceeds, or refers to, the elements 
previously mentioned. The reference of the word foris is one of the grammatical cohesions in the form of a particular lingual unit referring to other lingual units that follow or refer to the antecedent on the right, or referring to the newly mentioned element. Certain lingual units referring to other lingual units may be persona (pronoun), demonstrative (compassionate), and comparative (a lingual unit that serves to compare one element to another).

\section{Personal Pronounce Reference}

Persona reference is realized through pronominal persona, which includes first person (persona I), second (persona II), and third (persona III), either singular or plural. The single person pronominal I, II singular, single III exists in the form of free form (free morpheme) and some are bound (morpheme bound). As for pronouns persona I single form free .i.e., I 'kula', I 'sliraku', servant 'kawula', Pronominal persona II can be kowe 'you', sampeyan 'you', panjenengan 'you' andhika 'you' sliramu 'you', pronominal persona III can be panjenengane 'he/she' dheweke he/she '. As for the bound form is, ku, ne, mu. I.e., single person pronominal reference.

'Kula badhe sumela atur rumiyin// gegayutan kaliyan sarasehan Basa Jawi tanggal 28 September wingi/l/ Mugi ingkang boten saged rawuh dalu punika midhangetaken///'

'Saya ingin menyela sebentar// berkaitan dengan Sarasehan Bahasa Jawa tanggal 28 September 2014 kemarin/// Semoga yang tidak dapat hadir malam ini dapat mendengarkan///'.

In the above passage the word 'kula' includes anaphoric endophoric reference through a single free form personal pronounce.

\section{Demonstrative Pronominal}

Demonstrative pronoun can be divided into two, namely pronominal demonstrative time (temporal) and pronominal demonstrative place (lokasional). The current demonstrative pronominal time refers to the present time (such as saiki 'now'), past (like dhek wingi 'yesterday' and dhek biyen 'first'), will come (like tomorrow 'tomorrow' and next 'suk mben') and neutral time (such as 'morning' and 'noon' enjing). The demonstrative pronomina of a place refers to a place or location close to the speaker (ana kene 'here', kene 'here', iki 'this'), 
somewhat away with the speaker (kono 'over there', iku 'there'), away with Speakers (kana 'over there), and point explicit places (Madiun, Surakarta, Jogjakarta, etc.), i.e. demonstrative pronouns.

'Kula badhe sumela atur rumiyin// gegayutan kaliyan sarasehan Basa Jawi tanggal 28 September wingi/// Mugi ingkang boten saged rawuh dalu punika midhangetaken///'

'Saya ingin menyela sebentar// berkaitan dengan Sarasehan Bahasa Jawa tanggal 28 September 2014 kemarin/// Semoga yang tidak dapat hadir mala mini dapat mendengarkan///'

In the above speech there is a demonstrative pronominal demonstration of the past '28 September wingi 'refers to the last yesterday.

\section{E. Comparative Reference}

Comparative reference is one type of grammatical cohesion that is comparing two or more things that have similarities or similarities in terms of form, attitude, nature, character, behavior, and so on. Words commonly used to compare for example 'kaya' like ', pindha' bagai ', kadya' like ', similar' equal to '.

\section{F. Subtitution}

Substitution is one type of grammatical cohesion in the form of replacement of a particular lingual unit (which has been called) with other lingual units in the discourse to obtain a distinguishing element. Viewed in terms of lingual units, substitutions can be divided into nominal, verbal, phrasal, and causal substitutions.

\section{G. Nominal Subtitution}

Nominal substitution is the replacement of lingual units that are categorized as nouns (nouns) with other lingual units that are also categorized as nouns (Sumarlam, 2010: 47). One example of application of Nominal Substitution is on data (1.74).

"mucal lungguh meja, lha ngoten menika.. dados maringi conto ngoten nggih, maringi patuladhan." (1.74)

The word 'conto' is replaced by a lingual unit that is categorized as a noun with a lingual unit that is categorized as another noun ie the word 'patuladhan' as in the data (1.74). 


\section{H. Verbal substitution}

Verbal substitution is the replacement of lingual units categorized verbs (verbs) with other lingual units that are also categorized verbs (Sumarlam, 2010: 48). The application of the Verbal Sustitution is exemplified in the data (1.115).

"Njih mugi-mugi Pak.. menika wonten sms. Kula waos rumiyin nggih.. "Sugeng dalu.. jumbuh kaliyan dalu menika bab pitutur luhur, kejawi wau wonten tembang pocung, tembang kinanthi, menika wonten seratan badhe katuraken tembang pangkur. Niki kula waosaken rumiyin nggih tembang pangkuripun." (1.115)

The word 'katuraken' is replaced by lingual units categorized by verbs with lingual units that are categorized into other verbs such as 'waosaken' as in data (1.115).

\section{Phrasal Substitution}

Phrasal substitution is the replacement of certain lingual units in the form of words or phrases with other lingual units in the form of phrases (Sumarlam, 2010: 48).

An example of a phrasal ubstitution is on data (1.167).

"saged dipuntrapaken harian, jaman kula panjenengan taksih alit sekolah $\underline{\mathbf{S R}}$ ngantos dumugi ageng menika, menika tansah dipunwucalaken dateng sekolahan. Leres mboten Pak menika?" (1.167)

The word 'SR' is replaced by a lingual unit in the form of a word with another lingual unit in the form of the word 'sekolahan' as in data (1.167).

\section{J. Clausal Substitution}

Clausal substitution is the replacement of certain lingual units in the form of clauses or sentences with other lingual units in the form of words or phrases (Sumarlam, 2010: 49). One application of the c lausal substitution applies to the data (1.24)

A : "nanging kula pitados wonten dalem, tamtu midangetaken."

$B$ : "Lha nggih menika.. kula pitados.

Pada data (1.24) terdapat substitusi klausal yaitu tuturan A berupa satuan lingual kalimat disubstitusi oleh satuan lingual lain pada tuturan B yaitu kata 'menika'.

\section{Ellipsis}

Ellipsis is one type of grammatical cohesion in the form of removal or exposure of certain lingual units mentioned earlier. Lingual elements or units are words, phrases, clauses, sentences. The existence of the aforementioned then the speech becomes more effective and 
efficient discourse into cohesive, and motivate the reader to be more creative to find the elements that dilesapkan, and practical and communicate. In the discourse analysis the conceived elements (constituents) are commonly marked with zero or zero constituents (or with symbols $\emptyset$ ) at the place of occurrence.

Inggih, pakartining ngilmu luhung. Dados wewarah ingkang sak langkung sae gegayutan kaliyan pratap ingkang luhur, $\phi$ ingkang mulya menika perlu dipun gatosaken, $\phi$ dipun caaken. Awit menika tumrap ing tanah jawa, tumrap piyantun jawi.(2.75)

In the data (2.75) there occurred a lingual ellipsis unit of the word 'wewarah' which functions as the subject of the speech contained in the data (2.75). The same subject takes the ellipse twice, ie before the word ingkang mulya in the second statement, and before the word 'dipun caaken' in the third statement.

\section{K. Conjunction}

A series or conjunction is one type of grammatical cohesion that is done by connecting one element with another in the discourse. The conjunctions include the following. (1) cause-effect: reason, karana; (2) disagreement: ananging; (3) advantages (excessive): in fact, luwih-luwih; (4) exceptions (ekseptif): kajaba; (5) consessive: senajan, sinaosa; (6) the purpose; supados; (7) additions (additives): lan, sarta, saha; (8) option (alternative): utawa; (9) expectations (optative): muga-muga; (10) sequential: banjur, sateruse; (11) resistance: kosok balen, suwalike; (12) time: sakwise, sarampunge; (13) terms: menawa; (14) way: kanthi mangkono.

One of the examples of the use of conjunctions is in the following utterances.

“Amargi sampun kabutanan saking griya pak, dados wonten sekolahan menika kantun mupuk, kantun nambahi dawuhipun para dwija dhateng para murid menika. Pangintun kula ngaten Pak.” (1.173)

The conjunction 'amargi' on data (1.173) although at the beginning of the sentence, but still serves to state causation.

\section{Lexical Aspects}

The discourse composition in addition supported by grammatical cohesion is also supported by lexical aspects or lexical cohesion. Lexical cohesion is the relationship between elements in semantic discourse. To produce a unified discourse can be pursued by the 
selection of words in accordance with the contents of the intended discourse. The cohesive relationship created on the basis of the lexical aspect, with the choice of a harmonious word, expresses the relationship of meaning or semantic relation between the lingual unit of one to the other lingual units in the discourse. The lexical aspects of discourse can be divided into six types: (1) repetition, (2) synonym, (3) collocation, (4) hyponimi, (5) antonym, and (6) equivalence.

\section{Repetition}

Repetition is the repetition of lingual units (sounds, syllables, words, or parts of sentences) that are considered important to put pressure in an appropriate context. Gorys Keraf (1994: 127-128) cited by Sumarlam (2003: 127) states that based on the place of lingual units repeated in rows, clauses or sentences, repetition can be divided into eight kinds, ie repetition ephizeuxis, tautoles, anaphora, epistropha, simploke, mesodiplosis, epanalepsis, anadiplosis, and full repetition.

\section{Epizeuxis Repetition}

Epizeuxis repetition is the repetition of lingual units (words) that are emphasized several times in a row.

\section{Tautotes Repetition}

Tautotes repetition is the repetition of a lingual unit (a word) several times in a construction.

\section{Anaphora Repetition}

Anaphora repetition is the lingual unit repetition of the first word or phrase in each line or next clause / phrase. Repetitions on each line usually occur in poetry, whereas repetition of each sentence is in prose.

\section{Episthropa Repetition}

Episthropa repetition is the repetition of lingual units of words or phrases at the end of the line (in poetry) or ending sentences (in prose) respectively.

\section{Simploke Repetition}

Simploke repetition is the repetition of lingual units at the beginning and end of several lines or sentences in succession (different sentences).

\section{Mesodiplosis Repetition}

Mesodiplosis repetition is the repetition of lingual units in the middle of a row or sentence in a row.

\section{Epanalepsis Repetition}


The epanalepsis repetition is the lingual unit repetition that the last word / phrase of the line / phrase are the repetition of the first word / phrase (in the same sentence).

\section{Anadiplosis Repetition}

Anadiplosis repetition is the repetition of the last word / phrase from that line / phrase to the first word / phrase in the next line / phrase. In Indonesian poetry is called with a related poem, in Javanese poetry called purwakanthi basa / lumaksita.

\section{Complete or Full Repetition}

Complete or full reps are full or full lingual unit repetition. This repeating lingual unit can be either one line, or one whole sentence, or even one stanza or several sentences intact. Complete/ full reps are often found on the referent of a song.

\section{N. Synonym (Padan Kata)}

Synonym is one of the lexical aspects to support cohesion of discourse. Synonymy serves to establish a corresponding meaning relationship between particular lingual units with other lingual units in discourse. Based on the form of the lingual unit, the synonym can be divided into five kinds, namely (1) synonymy between morphemes (free) with morphemes (bound), (2) words with words, (3) words with phrases or otherwise, (4) phrases with phrases, (5) clause / sentence with clause / sentence..

\section{Synonymy between morphemes (free) with morphemes (bound)}

\section{Synonymous words with words}

Menika sampun kita onceki sesarengan. Malah anggen kita sarasehan ngrembag budi pakarti ngantos dumugi wewarah ingkang sinawung sekar Pucung tuwin sekar Kinanthi.

In the above speech the discourse of the discourse is supported by a lexical aspect in the form of a synonym between the word onceki in the first sentence with the word ngrembag in the second sentence. Both words are worth to discuss.

\section{Synonymous words with phrases or vice versa}

Ingkang baken taksih nggadahi niat pados ngelmu kudu taberi sinau. Taberi menika tlaten sregep mboten putus-putus, dados sinau ki ra dong-dongan, ora rog-rog asem.

In the discourse composition is supported by the lexical aspect in the form of a synonym between the word taberi in the first sentence with the phrase tlaten sregep in the 
second sentence. In addition, the cohesion is also supported by the use of the word segep with the condition described by the phrase mboten dashed, rau dong-dongan syn on the second sentence.

\section{Synonymy between phrase and phrase}

Cara basane pamit mbek Pak e Buk e nek mbiyen yo Pak e karo Yung e karo Mbok e ngoten....

In the above speech the discourse is supported by a lexical aspect in the form of a synonym between the phrase Yung $\mathbf{e}$ in the first sentence with the phrase Mbok e in the next sentence. Both expressions have equivalent meanings.

\section{Synonymy clause / sentence with clause / sentence.}

\section{O. Antonymy}

Antonyms can be interpreted as other names for things or other things; Or lingual units whose meanings are opposed / positioned with other lingual units. Antonimi is also called the opposition of meaning. By its nature, the opposition of meaning can be divided into five kinds, namely (1) absolute opposition, (2) polar opposition, (3) opposition relations, (4) hierarchical opposition, and (5) compound oppositions.

\section{Absolute Opposition}

The absolute opposition is an absolute contradiction of meaning. Example of absolute opposition as follows.

\section{Mboten namung timur, barat lan tengah ugi.}

In the above example there is an absolute opposition between the word east and west.

\section{Pole Opposition}

The pole opposition is an opposition of meaning that is not absolute, but is gradation. That is, there is a level of meaning in these words. Polar opposite words can be marked by the presence of gradations between the opposites of both words, for example with the reality of very rich, rich, rather rich. Example of polar opposition as follows.

Generasi penerus kita tiyang jawi sampun kathah ingkang kesupen sarto mboten peduli dateng budaya jawi. Kathah ingkang sampun nilaraken budaya leluhuripun antawisipun ing bab boso padintenan, antawisipun putra dateng ramanipun, para kaneman dateng para sepuh, sampun kathah ingkang tupangsuh anggenipun ngecaaken boso. 
In the above utterances there is a polar opposition between the word kaneman with the word elder in the second sentence. Both words are said to be in opposition to the poles because there is a gradation between the two oppositions, namely the reality of very young, young, rather young, rather old, old, and very old..

\section{The opposition of relations}

The opposition of relations is a complementary opposition of meaning. Since these oppositions are complementary, one word may be present because of the presence of another word into its opposition, or the presence of one word due to another. Example of opposition relationship as follows.

Mangga-mangga bapa-bapa, putra-putra, ibu lan bapa ingkang wonten dalem kadidika putra menika sampun ngantos dipunkirangi.

In the above speech there is an opposition relationship between the word Mother in the first sentence with Bapak in the same sentence. Mother as reality is possible because of its presence is equipped by Bapak and vice versa.

\section{Hierarchial Opposition}

Hierarchial opposition is the opposition of meaning which states a series of levels or levels. Lingual units with hierarchical positions are generally words that refer to the names of units of measure (length, weight, content), unit count names, calendars, and the like. Example of hierarchial opposition as follows.

Menika ngrembag bab kwajibanipun murid, murid menika saged taksih PAUD, sanajan sebatanipun sanes murid nek PAUD niku saged TK SD ngantos SMA saged sampun yuswa.

In the above utterances there is a hierarchical opposition between early childhood, kindergarten, elementary, junior high school, which describes the reality level or level of education from the lowest level (PAUD) to higher (SMA).

\section{Compound opposition}

Compound opposition is the opposition of meaning that occurs in several words (more than two). The difference between compounded opposition and polarity lies in the presence or absence of gradation as evidenced by its possibility coupled with the word somewhat, more, and deeply in the polar opposition, and not in the multiple oppositions. The difference with hierarchial opposition is that in hierarchial opposition there is a meaning which states that levels or levels which in higher or greater degree of reality always assume a lower or lesser degree. 


\section{DISCUSSION}

Memetri Budaya Jawi Broadcast which is the source of data in this thesis is a broadcast from Paguyuban Marsudi Kasusastran Jawi Sedyatama which was held in RRI Madiun. Research on grammatical cohesion on MBJ broadcasted by Paguyuban Marsudi Kasusastran Jawi Sedyatama. Based on the description of data analysis results and discussion in chapter four can be summarized as follows.

In the MBJ broadcast on October 8, 2014 and December 10, 2014 found four aspects of grammatical cohesion, namely reference, substitution, elepsis, and conjunction. Grammatical cohesion is dominated by the use of reference or reference aspects, of as many as 700 references, consisting of 344 persona references, demonstrative demonstrations of 356 , and comparative references not found in MBJ broadcasts. Substitution or recovery is as much as 58. The third grammatical aspect of elepsis or percolation is the aspect of the fewest in MBJ broadcast that is as much as 22 . The sets of conjunctions are found 224 . Thus, overall grammatical cohesion in MBJ broadcasts amounts to 1004. When presented and sorted from the most dominant then in the grammatical cohesion there are as many as $69.72 \%$ reference aspect; $22.31 \%$ aspect of conjunction; $5.77 \%$ of the substitution aspect; and $2.19 \%$ aspects of elepsis. In the MBJ broadcast by PMKJS in RRI Madiun this grammatical aspect is more dominant than the lexical aspect. In the MBJ broadcast the more dominant grammatical aspect is reference (reference) because on MBJ's oral discourse many participants and each participant is more likely to use the persona instead of using the direct mention of the participant name.

The oral discourse of MBJ radio broadcasts by PMKJS is cohesive, due to the presence of the benefits and functions of each aspect of cohesion so that it becomes a discourse. The oral discourse of MBJ radio broadcasts by PMKJS is a discourse considering these aspects, so the discourse sounds meaningful and unambiguous. The grammatical aspects contained in oral discourse MBJ radio broadcast by PMKJS found in the form of references, substitutions, ellipsis, and conjunctions. Here's the explanation.

Sumarlam in his book Teori dan Praktik Analisis Wacana (2003: 23-46) states that a unified discourse is a discourse which, when viewed in terms of the relationship of the form or structure of birth is cohesive, and seen in terms of the relationship of meaning or inner structure is coherent. In discourse analysis the shape or structure of discourse is called the grammatical aspect of discourse; whereas the facet of meaning or inner structure of discourse is called the lexical aspect of discourse. In the MBJ broadcast on October 8, 2014 
and December 10, 2014, four aspects of grammatical cohesion were found: references, substitutions, ellipsis, and conjunctions. Grammatical cohesion is dominated by the use of reference or reference aspects, of as many as 700 references, consisting of 344 personal references .The personal pronomina reference as follows:

"mbok bilih langkung prayogi, kepareng kula nyuwun tulung dipunaturaken pambagyaharja kaliyan supados para pamiyarsa sami pirsa, sumangga Pak Darmo.” (1.11)

In the sentence (1.11) there is the word ' $k u l a$ ' to replace the name of Mr. Agus. Thus, the word 'kula' is the word used with the first single person's pronominal reference.

Demonstrative reference aspect took as much as 356 and examples of demonstrative time are as follows:

"malah kala wau ingkang dawuhaken Pak Badawi, Sing iki piye ben iso numpak sepeda motor, sakniki malah mboten ngaten. Ora sepeda motor, nanging Avanza."

The phrase 'sak niki' in the data (1.118) which means now, wherein now is one of the types of demonstrative words to refer the state 'today'.

The comparative references are not found in MBJ broadcasts. The substitution reference took as much as 58 . The use of nominal substitution is as follows:

"mucal lungguh meja, lha ngoten menika.. dados maringi conto ngoten nggih, maringi patuladhan. " (1.9)

The word 'conto' is the replacement of a lingual unit categorized as a noun with a lingual unit that categorizes the other nouns i.e. the word 'patuladhan' as shown from data (1.9).

The third grammatical aspect of ellipsis is the fewest aspect in the MBJ broadcast which occur as much as 22 and the following is the example of utterance applying grammatical aspects of ellepsis as shown in data (1.3): 


\begin{tabular}{|l|l|}
\hline Heh, putu-ku, aja nganti matur kliru, & Heh, cucuku jangan sampai salah \\
Nganggo basa krama, & berbicara \\
Trapsila tan kena lali, & Memakai bahasa krama \\
Empan papan, unggah-ungguh, sarwa & Sopan satun jang sampai lupa, \\
tata. & Bisa menempatkan diri, tata krama \\
Sedyatama, paguyuban merdi ngelmu, & semua ditata. \\
Sastra lan budaya, & Sedyatama, paguyuban mencari ilmu, \\
Basa Jawi aja lali, & Sastra dan Budaya, \\
Awya nganti wastra lungset ing sampiran. & Bahasa Jawa jangan sampai lupa, \\
(N1/MBJ8) & Jangan sampai seperti kain tradisional \\
& yang kusam di sampiran. \\
\hline
\end{tabular}

The data (1.3) shows that there is a lingual unit in the form of a word, i.e. the word 'putuku' which serves as the subject utterance reflected from the data (1.3). The same subject is elapsed twice before the word 'nganggo' in the second statement, and before the word 'trapsila' in the third statement. The way of representing can be seen in (a), and if the speech is re-written into its complete form without being shown the ellipsis can be seen in section (b).

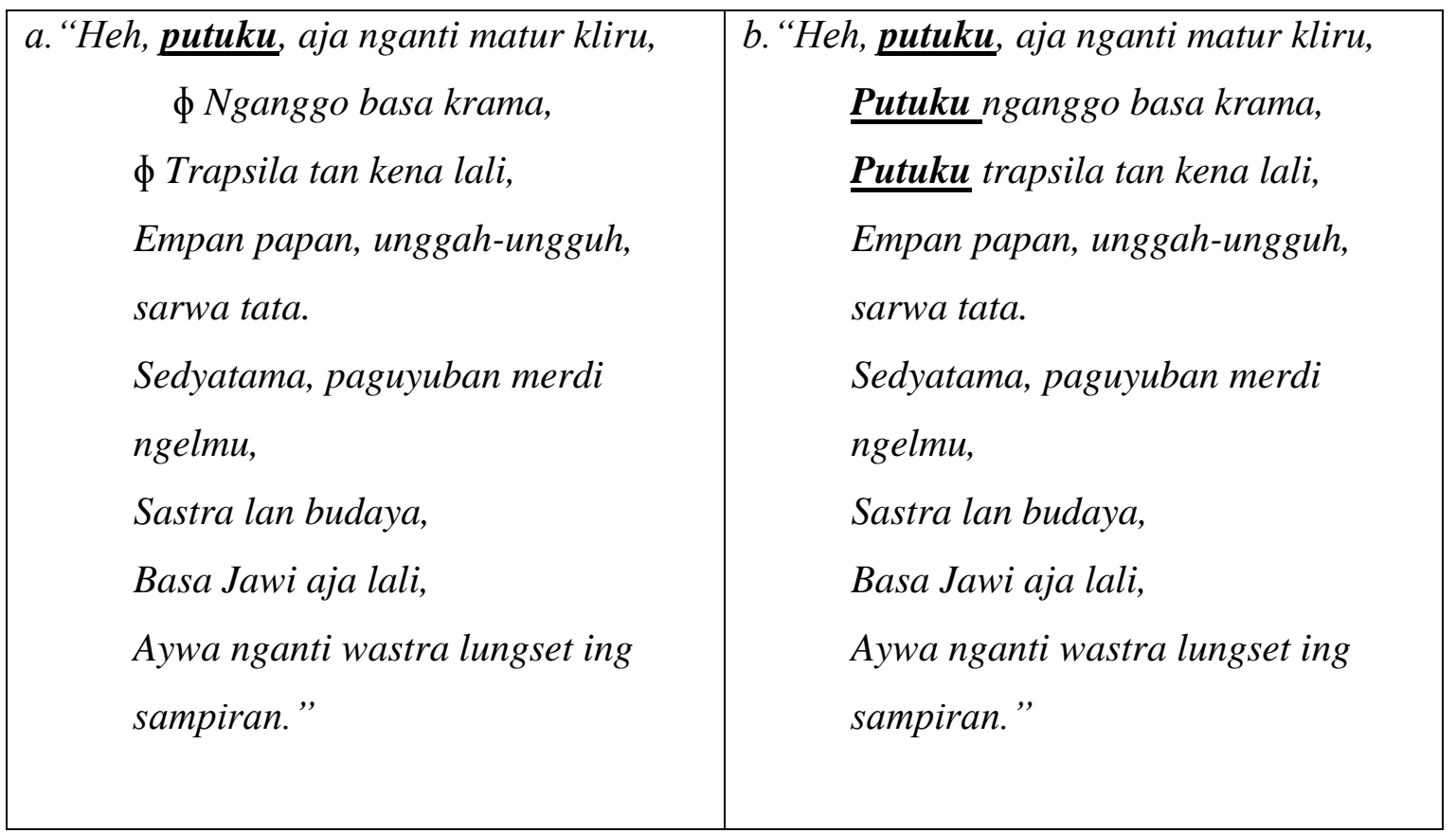

As the above analysis the occurrence of such ellipsis on (a) then the utterance looks more effective and efficient. The imprint function is invisible if it is written such as on (b). There 
is a grammatical aspect of 224 conjunctions and one example of its application can be seen from the word 'amargi' on data (1.173) is:

“Amargi sampun kabutanan saking griya pak, dados wonten sekolahan menika kantun mupuk, kantun nambahi dawuhipun para dwija dhateng para murid menika. Pangintun kula ngaten Pak.” (1.173)

The conjunction 'amargi' on data (1.173), although it occurs at the beginning of the sentence, but still serves to state the cause and effect.

Thus, overall grammatical cohesion in MBJ broadcasts amounts to 1004. In the MBJ broadcast by PMKJS in RRI Madiun this grammatical aspect is more dominant than the lexical aspect. In the MBJ broadcast the more dominant grammatical aspect is referencing because in MBJ's oral discourse many participants and each participant are more likely to use the persona instead of using the direct mention of the participant's name.

\section{CONCLUSION}

In the MBJ broadcast on October 8, 2014 and December 10, 2014, four aspects of grammatical cohesion were found: references, substitutions, elepsis, and conjunctions. Grammatical cohesion is dominated by the use of reference or reference aspects, of as many as 700 references, consisting of 344 persona references, demonstrative pronounce 356 , and comparative references not found in MBJ broadcasts. Substitution were found much as 58 data. The third grammatical aspect of elepsis or percolation is the aspect of the fewest in MBJ broadcast that is as much as 22. Conjunctions or conferences were found 224 conjunctions. Thus, overall grammatical cohesion in MBJ broadcasts amounts to 1004. In the MBJ broadcast the more dominant grammatical aspect is reference (reference) because on MBJ's oral discourse many participants and each participant is more likely to use the persona instead of using the direct mention of the participant name. 


\section{REFERENCES}

Abdul Chaer. 1994. Linguistik Umum. Jakarta: PT. Rineka Cipta.

Juita, Novia, 2016, Tindak Tutur Tokoh dalam Kaba: Pencerminan Kearifan dan Kesantunan Berbahasa Etnis Minangkabau, Humanus: Jurnal Ilmiah Ilmu-ilmu Humaniora, Vol 15, No 1 (2016), DOI: 10.24036/jh.v15i1.6416

Fatimah Djajasudarma. 1994. Wacana Pemahaman dan Hubungan Antar-unsur. IKAPI: PT. Eresco.

Gorys Keraf. 2002. Diksi Dan Gaya Bahasa. Jakarta: PT. Gramedia Pustaka Utama. , 2001. Komposisi. Ende Flores: Nusa Indah

Mulyana. 2005. Kajian Wacana Teori, Metode dan Aplikasi Prinsip-Prinsip Analisis Wacana. Yogyakarta: Penerbit Tiara Wacana.

Sudaryanto.1992. Metode Linguistik. Yogyakarta: Duta Wacana University Press.

, 1993. Metode dan Aneka Teknik Analisis Bahasa. Yogyakarta: Duta Wacana University Press.

Sumarlam. et.al. 2003. Teori dan Praktik Analisis Wacana. Surakarta: Pustaka Cakra. 2006. Analisis Wacana Tekstual dan Kontekstual. Surakarta: Fakultas Sastra Universitas Sebelas Maret.

Tim Penyusun Kamus Pusat Bahasa. Departemen Pendidikan Nasional. 1989. Kamus Besar Bahasa Indonesia. Jakarta: Balai Pustaka. 